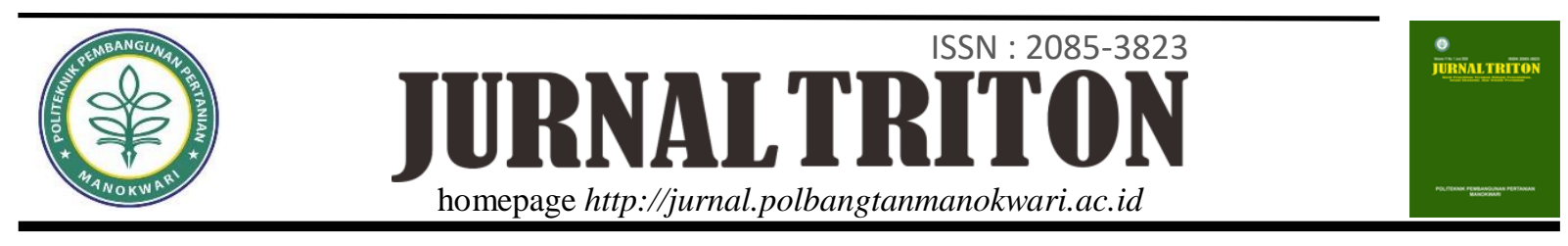

\title{
Motivasi Petani dalam Integrasi Sawit Sapi di Desa Perkebunan Tanjung Beringin Kecamatan Hinai Kabupaten Langkat
}

Yenny Laura Butarbutar ${ }^{1 *}$, Firman R.L Silalahi ${ }^{2}$

${ }^{1,2}$ Program Studi Penyuluhan Perkebunan Presisi, Jurusan Perkebunan, Polbangtan Medan

\begin{tabular}{l}
\hline \multicolumn{1}{c}{ ARTIKEL INFO } \\
\hline Sejarah artikel \\
Diterima 11/06/2020 \\
Diterima dalam bentuk revisi 25/06/2020 \\
Diterima dan disetujui 26/06/2020 \\
Tersedia online 30/06/2020 \\
\hline Kata kunci : \\
Faktor internal \\
Faktor eksternal \\
Integrasi \\
Korelasi spearman \\
Motivasi \\
\hline
\end{tabular}

\begin{abstract}
ABSTRAK
Sawit merupakan komoditas unggulan yang diperdagangkan secara luas dari subsektor perkebunan. Dilihat dari besarnya jumlah produksi kelapa sawit menjadikan komoditi kelapa sawit sebagai usaha yang masih diminati oleh masyarakat. Hal tersebut membuka peluang bagi pengembangan ternak sapi potong secara terintegrasi dengan memanfaatkan hijauan. Pada dasarnya integrasi ternak sapi dalam kebun kelapa sawit menjadi daur ulang sumber daya yang tersedia secara optimal. Penelitian ini bertujuan untuk mengetahui tingkat motivasi petani dalam penerapan integrasi sawit sapi serta faktor-faktor internal dan eksternal yang mempunyai hubungan dengan motivasi petani dalam menerapkan integrasi sawit sapi. Metode penentuan sampel adalah purposive (sengaja) sebanyak 46 orang petani di daerah penelitian. Penelitian ini mengumpulkan data primer melalui wawancara secara langsung dan mendalam kepada para sampel dengan menggunakan kuesioner yang telah dipersiapkan. Metode analisis data antara lain perhitungan matematis tingkat motivasi petani dan korelasi Spearman. Kesimpulan penelitian menunjukkan tingkat motivasi ekonomi dan sosiologis masing-masing sebesar 56,09\% dan $51,74 \%$ dan berada pada kategori sedang. Selanjutnya motivasi ekonomi tidak memiliki hubungan yang signifikan dengan faktor-faktor internal, tetapi memiliki hubungan yang signifikan dengan 3 faktor eksternal dalam penerapan integrasi sawit sapi. Motivasi sosiologis memiliki hubungan yang signifikan dengan 2 faktor internal dan 1 faktor eksternal dalam penerapan integrasi sawit sapi.
\end{abstract}

CC 2020 Politeknik Pembangunan Pertanian Manokwari 


\section{ABSTRACT}

Palm is the main commodity that is widely traded from the plantation sub-sector. Judging from the large amount of palm oil production, it makes palm oil as a business that is still in demand by the community. This opens up opportunities for integrated beef cattle development by utilizing forage. Basically the integration of cattle in oil palm plantations to be recycled available resources optimally. The study is aimed at identifying the motivational rates of farmers in the application of liquidity and internal and external factors that relate to the motivation of farmers to apply the integration of oil palm-beef. The method of germinating samples is as purposive as 46 farmers in the research area. This study collected primary

\section{PENDAHULUAN}

Indonesia adalah negara yang kaya akan sumber daya alamnya. Kekayaan berlimpah tersebut tentu menjadi peluang untuk memperoleh keuntungan yang besar. Hal ini memungkinkan Indonesia mengembangkan berbagai jenis dan varietas hasil perkebunan yang tumbuh di berbagai daerah. Perkebunan juga menjadi tulang punggung utama bagi Indonesia dalam menahan krisis perekonomian. Beberapa komoditas perkebunan Indonesia yang berhasil bersaing di pasar internasional antara lain adalah kelapa sawit, rempah-rempah, kakao, karet, kopi, dan vanili (Chandrayani dan Natha, 2016).

Salah satu komoditas unggulan yang diperdagangkan secara luas dari subsektor perkebunan, yaitu kelapa sawit (Elaeis guineensis). Berdasarkan sumber data dari BPS Provinsi Sumatera Utara (2018) mengenai statistik kelapa sawit Indonesia diketahui bahwa luas areal perkebunan kelapa sawit terdiri dari perkebunan besar negara, perkebunan besar swasta, dan perkebunan data through direct and in-depth interviews with samples using a prepared questionnaire. Data analysis methods include the mathematical rate of motivation for the farmer and Spearman's correlation. Research conclusions a current rate of economic and sociological motivation at 56,09\% and $51,74 \%$ respectively and at a moderate category. Economic motivation in turn does not have a significant correlate with internal factors, but has a significant correlate with three external factors in the integration of oil palm-beef. Sociological motivation in turn have a significant correlate with two internal factors and one external factor in the integration of oil palm-beef.

rakyat di Sumatera Utara tahun 2017 mencapai 1.348.306 ha dengan jumlah produksi mencapai 4.144.620 ton. Dilihat dari besarnya jumlah produksi kelapa sawit tersebut menjadikan komoditi kelapa sawit sebagai usaha yang masih diminati oleh masyarakat. Hal tersebut membuka peluang bagi pengembangan ternak sapi potong secara terintegrasi dengan memanfaatkan hijauan berupa rumput dan legum penutup tanah, limbah kebun seperti pelepah sawit, dan limbah pengolahan Crude Palm Oil (CPO) sebagai sumber pakan.

Limbah kelapa sawit yang dihasilkan oleh tanaman kelapa sawit cukup beranekaragam dan besar jumlahnya. Berbagai jenis limbah kelapa sawit dapat memberikan manfaat yang besar untuk memenuhi kebutuhan manusia. Meskipun limbah padat industri kelapa sawit mengandung bahan organik yang tinggi namun dapat berdampak pada pencemaran lingkungan apabila tidak dilakukan penanganan limbah secara tepat. Pengelolaan hijauan pakan ternak yang berasal 
dari limbah pertanian umumnya belum dilakukan oleh petani/peternak hal ini terjadi karena petani kekurangan waktu dan tenaga kerja serta belum tersedianya teknologi pengolahan yang efisien dan praktis (Winarso dalam Suryana, 2015).

Disisi lain ada salah satu komoditas diluar perkebunan yang menjadi kontroversi baik bagi petani maupun pemerintah, yaitu impor daging sapi. Hal ini disebabkan program swasembada sapi belum mampu menghasilkan swasembada daging secara nasional (Ditjennak, 2010) bahkan volume impor daging diperkirakan akan meningkat pada tahun-tahun mendatang (Matondang dan Rusdiana, 2013). Sulitnya mencapai swasembada daging sapi salah satunya disebabkan karena jumlah populasi ternak sapi belum mencukupi. Berdasarkan data pada tahun 2017, produksi daging sapi dan kerbau nasional sebesar 513 ribu ton (Kementan, 2015), belum memenuhi kebutuhan daging yang mencapai 604 ribu ton (Kompas, 2017).

Berdasarkan hal tersebut, maka sasaran utama dalam program peningkatan produksi daging sapi adalah dengan peningkatan populasi sapi. Sumber produksi daging sapi nasional, antara lain (1) sapi lokal yaitu sapi potong, sapi perah jantan, dan sapi perah betina afkir yang sebagian besar adalah sapi potong; dan (2) sapi bakalan (feeder steer) yang diimpor dari Australia dan digemukkan di Indonesia selama sekitar 100 hari (Direktorat Pangan dan Pertanian/Bappenas, 2013).

Salah satu aspek yang mempengaruhi produktivitas dari ternak sapi adalah ketersediaan pakan yang cukup dimana dalam biaya produksi biaya pakan mencapai $60-80 \%$ dari keseluruhan biaya produksi. Untuk memenuhi kebutuhan pakan ternak tersebut perkebunan kelapa sawit dapat dijadikan sebagai sumber untuk pakan hijauan ternak. Kegiatan ini dapat dikatakan sebagai integrasi antara sawit dan sapi. Pengembangan sistem integrasi perkebunan kelapa sawit dengan ternak sapi dapat dilakukan dengan memanfaatkan lahan di antara tanaman perkebunan untuk menanam hijauan pakan dan sebagai padang penggembalaan ternak. Sumber pakan ternak sapi tersebut akan berasal dari hijauan rumput dan legum penutup tanah ataupun pelepah kelapa sawit yang ada di sekitar perkebunan kelapa sawit. (Bamualim et al., 2015). Dalam satu tahun tanaman kelapa sawit mampu menghasilkan 20-30 pelepah daun. Untuk tanaman berumur 3-8 tahun jumlah pelepah optimal sekitar 48-56 sementara untuk tanaman lebih dari 8 tahun jumlah pelepah sekitar 40-48 pelepah (Fauzi et al., 2012).

Pada dasarnya integrasi ternak sapi dalam kebun kelapa sawit menjadi daur ulang sumber daya yang tersedia secara optimal. Hasil samping dari limbah perkebunan dapat dimanfaatkan sebagai bahan pakan ternak, sedangkan kotoran ternak dan sisa pakan ternak serta hasil pemanenan yang tidak dapat digunakan untuk pakan dapat didekomposisi menjadi kompos sebagai penyedia unsur hara untuk meningkatkan kesuburan lahan (Sirait $e t$ al., 2015).

$$
\text { Kabupaten Langkat khususnya }
$$

Kecamatan Hinai memiliki luas areal 
perkebunan rakyat mencapai 765 ha dengan produksi 9.630 ton, sedangkan untuk Desa Perkebunan Tanjung Beringin sendiri mencapai 3.641,25 ha perkebunan garapan milik perusahaan. Selanjutnya dengan potensi sumber daya alam tersebut, sumber daya manusia serta peluang pasar lokal, maka sangat berpeluang mendukung swasembada daging sapi dengan menjadikan wilayah tersebut sebagai sentra perternakan sapi yang tidak terlepas dari dukungan pemerintah. Langkah awal yang dilakukan oleh pemerintah adalah dengan diadakannya pelatihan integrasi sawit sapi di Kecamatan Hinai khususnya di Desa Perkebunan Tanjung Beringin.

Kegiatan integrasi kelapa sawit dengan ternak sapi diharapkan dapat terlaksana dengan sebagaimana mestinya guna mewujudkan pertanian terpadu yang bebas dari limbah dan pemakaian pestisida berbasis tanaman kelapa sawit dan ternak sapi di kecamatan tersebut. Akan tetapi, pada kenyataannya di Desa Perkebunan Tanjung Beringin itu sendiri penerapan integrasi sawit sapi masih kurang berjalan sebagaimana mestinya, petani telah menerapkan integrasi sawit sapi, tetapi masih dengan model integrasi semi intensif. Selain dibantu oleh dukungan dari perusahaan perkebunan, maka untuk tercapainya program integrasi sawit sapi tersebut perlu juga adanya dukungan yang besar dari petani yang berperan sebagai pelaku utama dalam pelaksanaan kegiatan integrasi sawit sapi tersebut. Perlu adanya motivasi serta dorongan yang kuat dari dalam diri petani agar mereka mau dan semangat untuk berusaha tani dengan sistem integrasi sawit sapi yang lebih kompleks.
Berdasarkan hal hal tersebut, maka penulis tertarik untuk melakukan penelitian tentang "Motivasi Petani dalam Integrasi Sawit Sapi dengan Pola Kemitraan di Desa Perkebunan Tanjung Beringin Kecamatan Hinai Kabupaten Langkat Provinsi Sumatera Utara" untuk mengetahui bagaimana tingkat motivasi petani dalam penerapan integrasi sawit sapi serta hubungan antara faktor-faktor internal dan eksternal petani dengan motivasi petani dalam penerapan integrasi sawit sapi di lokasi penelitian tersebut.

\section{METODE}

Penelitian ini termasuk jenis penelitian kualitatif untuk mengetahui tingkat motivasi dan hubungan antara faktor-faktor internal dan eksternal petani dengan motivasi petani dalam penerapan integrasi sawit sapi di Desa Perkebunan Tanjung Beringin Kecamatan Hinai Kabupaten Langkat. Berdasarkan hal tersebut, maka penelitian ini terlebih dahulu melakukan uji validitas dan reliabilitas dari kuesioner yang akan digunakan terhadap responden lain di luar sampel yang telah ditentukan. Uji validitas merupakan patokan untuk menyatakan bahwa instrumen ukur cocok dan tepat untuk mengukur suatu fakta tertentu. Uji validitas dilakukan agar mengetahui kelayakan butir-butir dalam suatu daftar pertanyaan maupun pernyataan. Sedangkan uji reliabilitas yang dimaksudkan apabila instrumen ukur digunakan berkali-kali tetap memberikan hasil (nilai) yang sama (konsisten). Reabilitas merupakan sejauh mana suatu alat pengukur dapat dipercaya dan dapat diandalkan (Prijambodo, 2014).

Metode Pengumpulan Data 
Penelitian ini mengumpulkan data primer melalui wawancara secara langsung dan mendalam kepada para sampel dengan menggunakan kuesioner yang telah dipersiapkan. Kuesioner tersebut mencakup semua indikator dan kriteria untuk setiap variabel yang digunakan dalam penelitian ini. Variabel, indikator, dan kriteria yang digunakan dalam penelitian ini dapat dilihat pada Tabel 1 berikut.

Tabel 1. Variabel, Indikator, dan Kriteria yang Digunakan

\begin{tabular}{|c|c|c|c|}
\hline Variabel & Indikator & Kriteria & Skor \\
\hline \multicolumn{4}{|c|}{$\begin{array}{l}\text { Faktor Internal } \\
\text { 1. Pendidikan }\end{array}$} \\
\hline \multirow[t]{6}{*}{$\begin{array}{l}\text { a. Pendidikan } \\
\text { Formal }\end{array}$} & $\begin{array}{l}\text { Pendidikan } \\
\text { terakhir yang } \\
\text { dicapai oleh } \\
\text { petani : }\end{array}$ & & \\
\hline & $\begin{array}{l}\text { 1. Tamat } \geq \\
\text { D4/S1 }\end{array}$ & $\begin{array}{c}\text { 1. Sangat } \\
\text { tinggi }\end{array}$ & 5 \\
\hline & 2. Tamat D3 & 2. Tinggi & 4 \\
\hline & 3. Tamat SMA & 3. Sedang & 3 \\
\hline & 4. Tamat SMP & 4. Rendah & 2 \\
\hline & 5. Tamat SD & $\begin{array}{l}\text { 5. Sangat } \\
\text { rendah }\end{array}$ & 1 \\
\hline \multirow[t]{7}{*}{$\begin{array}{l}\text { b. Pendidikan } \\
\text { Nonformal }\end{array}$} & $\begin{array}{l}\text { Frekuensi petani } \\
\text { dalam } \\
\text { mengikuti }\end{array}$ & & \\
\hline & $\begin{array}{l}\text { kegiatan } \\
\text { pelatihan }\end{array}$ & & 5 \\
\hline & 1. $4 \mathrm{x}$ setahun & $\begin{array}{l}\text { 1. Sangat } \\
\text { tinggi }\end{array}$ & $\begin{array}{l}4 \\
3\end{array}$ \\
\hline & 2. $3 \times$ setahun & 2. Tinggi & 2 \\
\hline & 3. $2 \times$ setahun & 3. Sedang & 1 \\
\hline & 4. $1 \times$ setahun & 4. Rendah & \\
\hline & 5. Tidak pernah & $\begin{array}{l}\text { 5. Sangat } \\
\text { rendah }\end{array}$ & \\
\hline \multirow[t]{7}{*}{$\begin{array}{l}\text { 2. Pengala- } \\
\text { man beternak }\end{array}$} & $\begin{array}{l}\text { Pengalaman } \\
\text { dalam } \\
\text { melakukan }\end{array}$ & & \\
\hline & $\begin{array}{l}\text { kegiatan } \\
\text { beternak: }\end{array}$ & & 5 \\
\hline & 1. $>15$ tahun & $\begin{array}{l}\text { 1. Sangat } \\
\text { tinggi }\end{array}$ & $\begin{array}{l}4 \\
3\end{array}$ \\
\hline & $\begin{array}{l}2 .>10-15 \\
\text { tahun }\end{array}$ & 2. Tinggi & $\begin{array}{l}2 \\
1\end{array}$ \\
\hline & $\begin{array}{l}3 .>5-10 \\
\text { tahun }\end{array}$ & 3. Sedang & \\
\hline & 4. $>1-5$ tahun & 4. Rendah & \\
\hline & 5. $<1$ tahun & $\begin{array}{l}\text { 5. Sangat } \\
\text { rendah }\end{array}$ & \\
\hline 3. Jumlah & Jumlah ternak & & \\
\hline
\end{tabular}

\begin{tabular}{|c|c|c|c|}
\hline Variabel & Indikator & Kriteria & Skor \\
\hline \multirow[t]{8}{*}{ ternak } & sapi yang & & \\
\hline & dimiliki & & \\
\hline & petani : & & 5 \\
\hline & 1. > 17 ekor & $\begin{array}{l}\text { 1. Sangat } \\
\text { tinggi }\end{array}$ & 4 \\
\hline & 2. $13-16$ ekor & 2. Tinggi & 3 \\
\hline & 3. $9-12$ ekor & 3. Sedang & 2 \\
\hline & 4. $5-8$ ekor & 4. Rendah & 1 \\
\hline & 5. $1-4$ ekor & $\begin{array}{l}\text { 5. Sangat } \\
\text { rendah }\end{array}$ & \\
\hline \multirow{8}{*}{$\begin{array}{l}\text { 4. Tingkat } \\
\text { kosmopolitan }\end{array}$} & Frekuensi petani & & \\
\hline & $\begin{array}{l}\text { dalam } \\
\text { menoikuti }\end{array}$ & & \\
\hline & $\begin{array}{l}\text { kegiatan } \\
\text { penyuluhan : }\end{array}$ & & \\
\hline & 1. $2 \mathrm{x}$ sebulan & $\begin{array}{l}\text { 1. Sangat } \\
\text { tinggi }\end{array}$ & 5 \\
\hline & 2. $1 \mathrm{x}$ sebulan & 2. Tinggi & 4 \\
\hline & 3. $2 \times 6$ bulan & 3. Sedang & 3 \\
\hline & 4. $1 \mathrm{x}$ setahun & 4. Rendah & 2 \\
\hline & 5. Tidak pernh & $\begin{array}{l}\text { 5. Sangat } \\
\text { rendah }\end{array}$ & 1 \\
\hline
\end{tabular}

Faktor Eksternal

5. Dukungan Adanya pihak luar keterlibatan petani pemerintah dalam memberi bantuan untuk mendukung integrasi sawit sapi

1. Pengadaan alat

1. Sangat 5

2. Pengadaan pelatihan 3. Peningkatan intensitas penyuluhan 4. Pengadaan sosialisasi

5. Pemberian bantuan ternak 6. Ketersedia- Ketersediaan an kredit usahatani sumber kredit (BRI, Koperasi, Pegadaian, dan lain-lain)

1. $>3$ sumber

kredit tinggi

2. Tinggi 4

3. Sedang 3

4. Rendah 2

5. Sangat 1 rendah

7. Ketersedia2. 3 sumber kredit 3. 2 sumber kredit

4. 1 sumber kredit

5. Tidak ada sumber kredit 1. Sangat 5 tinggi

2. Tinggi 4

3. Sedang 3

4. Rendah 2

5. Sangat 1 rendah alat dan bahan 


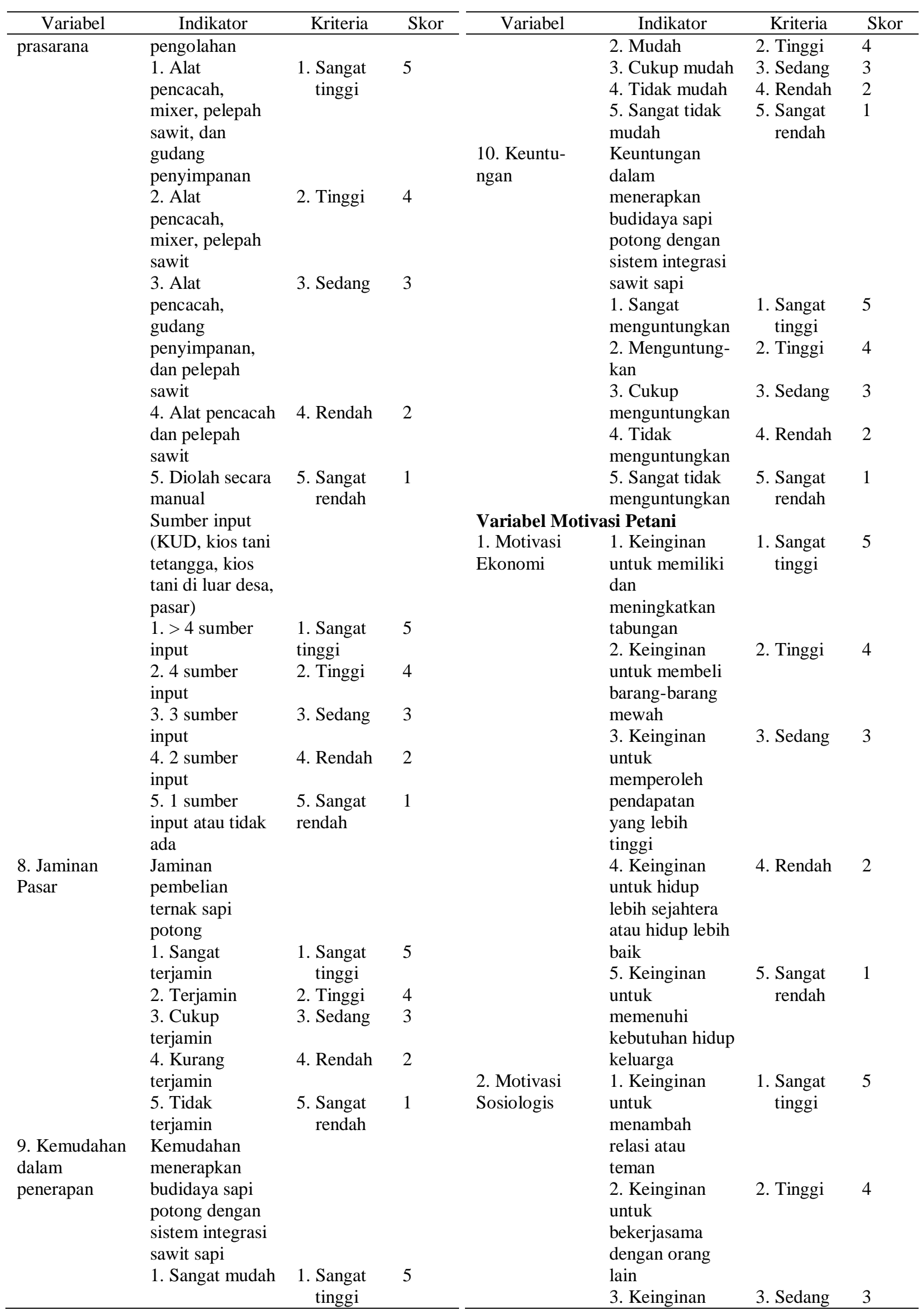




\begin{tabular}{llll}
\hline Variabel & \multicolumn{1}{c}{ Indikator } & Kriteria & Skor \\
\hline & untuk & & \\
mempererat & & \\
kerukunan & & \\
4. Keinginan & 4. Rendah & 2 \\
untuk dapat & & \\
bertukar & & \\
pendapat & & \\
5. Keinginan & 5. Sangat & 1 \\
untuk & rendah & \\
memperoleh & & \\
bantuan dari & & \\
orang lain & & \\
\hline
\end{tabular}

\section{Metode Penentuan Sampel}

Populasi yang digunakan dalam penelitian ini adalah semua petani yang memiliki ternak dan berusahatani ternak di Desa Perkebunan Tanjung Beringin Kecamatan Hinai Kabupaten Langkat sebanyak 85 orang. Berdasarkan jumlah populasi tersebut, maka dalam menentukan ukuran sampel dalam penelitian ini menggunakan metode Slovin dengan tingkat signifikansi sebesar $10 \%$ yang dapat dirumuskan sebagai berikut (Riadi, 2015).

$\mathrm{S}=\frac{N}{N\left(d^{2}\right)+1}$

Keterangan :

$\mathrm{S}=$ jumlah sampel

$\mathrm{N}=$ jumlah populasi

$\mathrm{d}=$ tingkat signifikansi/error yang

dikehendaki

Berdasarkan rumus Slovin tersebut, maka ukuran sampel dalam penelitian ini sebanyak 46 orang petani. Selanjutnya, metode yang digunakan untuk menarik 46 orang sampel petani tersebut adalah purposive (sengaja) dengan pertimbangan objektif untuk mencapai tujuan dalam penelitian ini, maka peneliti memilih sampel dengan kriteria bahwa petani sawit tersebut berstatus sebagai petani yang memiliki ternak sapi, anggota kelompok tani/kelompok ternak, telah mengikuti pelatihan pakan ternak dan biogas, serta telah bermitra dengan perusahaan perkebunan LNK yang ada di Desa Perkebunan Tanjung Beringin Kecamatan Hinai Kabupaten Langkat Provinsi Sumatera Utara yang menjadi lokasi penelitian ini dilaksanakan.

\section{Metode Analisis Data}

Berdasarkan hasil uji validitas dan reliabilitas, maka dapat dilakukan pengumpulan data melalui kuesioner yang ditanyakan secara langsung kepada para sampel untuk kemudian dianalis dengan 2 (dua) metode, antara lain :

1. Metode analisis tingkat motivasi petani dalam integrasi sawit sapi dengan rumus sebagai berikut.

$\mathrm{Na}=\frac{\text { Nilai skor hasil perolehan data }}{\text { Nilai skor tertinggi }} \times 100 \%$

Kriteria penarikan kesimpulan :

0 s.d $20 \%=$ motivasi sangat rendah

$>20$ s.d $40 \%=$ motivasi rendah

$>40$ s.d $60 \%=$ motivasi sedang

$>60$ s.d $80 \%=$ motivasi tinggi

$>80$ s.d $100 \%=$ motivasi sangat tinggi

2. Metode Korelasi Spearman $\left(\mathrm{r}_{\mathrm{s}}\right)$ untuk mengukur keeratan hubungan antara dua variabel yang tidak berdistribusi normal dan variansnya berbeda atau dengan kata lain data yang dikumpulkan menggunakan skala nominal atau ordinal yang dirumuskan sebagai berikut. 
$\mathrm{r}_{\mathrm{s}}=1-\frac{6 \sum_{i}^{n}=1 d^{2}}{n\left(n^{2}-1\right)}$

Keterangan :

$\mathrm{r}_{\mathrm{s}}=$ nilai koefisien korelasi Spearman

$\mathrm{d}=$ perbedaan setiap pasangan rangking

$\mathrm{n}=$ jumlah sampel

Apabila telah didapatkan nilai koefisien korelasi Spearman, maka perlu dilakukan uji t untuk melihat nyata tidaknya hubungan antar variabel yang dirumuskan sebagai berikut.

$\mathrm{t}=\mathrm{r}_{\mathrm{s}} \sqrt{\frac{n-2}{1-\left(r s^{2}\right)}}$

Kriteria penarikan kesimpulan :

1. Apabila $\mathrm{t}$ hitung $>\mathrm{t}$ tabel, maka ada hubungan yang nyata antar variabel.

2. Apabila $\mathrm{t}$ hitung $\leq \mathrm{t}$ tabel, maka tidak ada hubungan yang nyata antar variabel.

(Supriana dan Barus, 2010).

\section{HASIL DAN PEMBAHASAN}

\section{Analisis Tingkat Motivasi Petani dalam Penerapan Integrasi Sawit Sapi}

Berdasarkan hasil uji validitas dan reliabilitas yang telah dilakukan oleh penulis diketahui bahwa seluruh butir instrumen pertanyaan dalam kuesioner yang digunakan dalam penelitian ini adalah valid dan layak digunakan. Oleh karena itu, data yang telah dikumpulkan dari hasil wawancara langsung kepada para sampel dengan menggunakan kuesioner ditabulasi dan dianalisis untuk mengetahui tingkat motivasi petani dalam penerapan integrasi sawit sapi di daerah penelitian.

Motivasi petani dalam penelitian ini terdiri dari 2 (dua), yaitu motivasi ekonomi dan motivasi sosiologis. Berdasarkan hasil analisis data diperoleh hasil bahwa jumlah skor yang diperoleh untuk pertanyaan mengenai motivasi ekonomi adalah sebesar 129, sedangkan total skor maksimum sebesar 230 . Oleh karena itu, dengan menggunakan metode perhitungan tingkat motivasi petani diperoleh hasil bahwa tingkat motivasi ekonomi petani dalam penerapan integrasi sawit sapi sebesar $56,09 \%$ yang termasuk kategori sedang. Hal ini menunjukkan bahwa motivasi ekonomi yang mendorong para sampel dalam menerapkan integrasi sawit sapi adalah keinginan untuk memperoleh pendapatan yang lebih tinggi.

Selanjutnya, untuk hasil analisis data diperoleh juga hasil bahwa jumlah skor yang diperoleh untuk pertanyaan mengenai motivasi sosiologis adalah sebesar 119, sedangkan total skor maksimum sebesar 230. Oleh karena itu, dengan menggunakan metode perhitungan tingkat motivasi petani diperoleh hasil bahwa tingkat motivasi ekonomi petani dalam penerapan integrasi sawit sapi sebesar 51,74\% yang termasuk kategori sedang. Hal ini menunjukkan bahwa motivasi sosiologis yang mendorong para sampel dalam menerapkan integrasi sawit sapi adalah keinginan untuk mempererat kerukunan.

\section{Analisis Hubungan Faktor-Faktor Internal dan Eksternal dengan Motivasi Ekonomi Petani dalam Integrasi Sawit Sapi}

Adapun hasil analisis data tentang hubungan antara faktor-faktor internal dan eksternal dengan motivasi ekonomi petani dalam integrasi sawit sapi di daerah penelitian yang dilakukan dengan menggunakan uji korelasi Spearman dapat dilihat pada Tabel 2 berikut.

Tabel 2. Analisis Hubungan Faktor-Faktor Internal dan Eksternal dengan 
Motivasi Ekonomi Petani dalam

Integrasi Sawit Sapi

\begin{tabular}{|c|c|c|c|c|}
\hline Variabel & $r_{s}$ & Sig & $\mathrm{t}$ hit & $\mathrm{t}$ tabel \\
\hline \multicolumn{5}{|l|}{ Faktor Internal } \\
\hline $\begin{array}{l}\text { 1. Pendidikan : } \\
\text { a. Pendidikan } \\
\text { Formal }\end{array}$ & 0,173 & 0,251 & 1,182 & 2,015 \\
\hline b. Pendidikan & $-0,130$ & 0,390 & $-0,087$ & 2,015 \\
\hline $\begin{array}{l}\text { 2. Pengalaman } \\
\text { beternak }\end{array}$ & 0,126 & 0,404 & 0,082 & 2,015 \\
\hline $\begin{array}{l}\text { 3. Jumlah } \\
\text { ternak }\end{array}$ & $-0,032$ & 0,834 & $-0,212$ & 2,015 \\
\hline $\begin{array}{l}\text { 4. Tingkat } \\
\text { Kosmopolitan }\end{array}$ & $-0,014$ & 0,926 & $-0,092$ & 2,015 \\
\hline $\begin{array}{l}\text { Faktor } \\
\text { Eksternal }\end{array}$ & & & & \\
\hline $\begin{array}{l}\text { 5. Dukungan } \\
\text { dari pihak luar }\end{array}$ & $-0,365^{*}$ & 0,013 & $-2,793$ & 2,015 \\
\hline $\begin{array}{l}\text { 6. Ketersedia- } \\
\text { an Sumber }\end{array}$ & $0,318^{*}$ & 0,031 & 2,346 & 2,015 \\
\hline Kredit & & & & \\
\hline $\begin{array}{l}\text { 7. Ketersedia- } \\
\text { an Sarana }\end{array}$ & & & & \\
\hline $\begin{array}{l}\text { Prasarana : } \\
\text { a. Ketersedia- } \\
\text { an Alat dan } \\
\text { Bahan }\end{array}$ & $0,324 *$ & 0,028 & 2,401 & 2,015 \\
\hline $\begin{array}{l}\text { Bahan } \\
\text { b. Ketersedia- } \\
\text { an Sumber }\end{array}$ & $-0,042$ & 0,780 & $-0,279$ & 2,015 \\
\hline Input & & & & \\
\hline $\begin{array}{l}\text { 8. Jaminan } \\
\text { Pasar }\end{array}$ & $-0,002$ & 0,988 & $-0,013$ & 2,015 \\
\hline $\begin{array}{l}\text { 9. Kemudahan } \\
\text { dalam }\end{array}$ & $-0,122$ & 0,421 & $-0,821$ & 2,015 \\
\hline $\begin{array}{l}\text { Penerapan } \\
\text { 10. Keuntu- } \\
\text { ngan }\end{array}$ & 0,055 & 0,718 & 0,365 & 2,015 \\
\hline
\end{tabular}

Berdasarkan Tabel 2 di atas diketahui bahwa semua faktor internal (pendidikan, pengalaman beternak, jumlah ternak, dan tingkat kosmopolitan) serta faktor-faktor eksternal (ketersediaan sumber input, jaminan pasar, kemudahan dalam penerapan, dan keuntungan) tidak memiliki hubungan yang signifikan dengan motivasi ekonomi petani dalam integrasi sawit sapi. Sedangkan faktorfaktor eksternal yang memiliki hubungan yang signifikan dengan motivasi ekonomi petani dalam integrasi sawit sapi, antara lain:

a. Dukungan dari pihak luar dengan diperolehnya nilai $t$ hitung $(2,793)>t$ tabel $(2,015)$. Hal ini didukung oleh hasil penelitian Ruhimat (2015) yang menyatakan dukungan dari pihak luar merupakan faktor yang berpengaruh tidak langsung terhadap motivasi petani.

b. Ketersediaan sumber kredit dengan diperolehnya nilai $\mathrm{t}$ hitung $(2,346)>\mathrm{t}$ tabel $(2,015)$. Hal ini didukung oleh hasil penelitian Silalahi (2015) yang menyatakan bahwa terdapat hubungan signifikan antara ketersediaan kredit usahatani dengan motivasi ekonomi petani, dalam penelitian tersebut dikatakan juga bahwa petani dapat menggunakan ketersediaan kredit dengan baik dan berkesinambungan.

c. Ketersediaan alat dan bahan dengan diperolehnya nilai $t$ hitung $(2,401)>t$ tabel $(2,015)$. Hal ini didukung oleh hasil penelitian Rukka dan Arman (2013) yang menyatakan ketersediaan sarana dan prasarana sebagai suatu faktor penunjang kemajuan usahatani yang berhubungan nyata positif. Ketersediaan sarana dan prasarana adalah yang dibutuhkan petani serta kemudahan petani dalam memperoleh alat dan bahan yang dibutuhkan. Sesuai dengan kenyataan dilapangan bahwa kendala yang dialami oleh petani dalam integrasi sawit sapi dengan pola kemitraan saat ini adalah tidak adanya alat dan bahan yang memadai, khususnya dalam pengolahan pakan ternak dari pelepah kelapa sawit yang masih dilakukan secara 
manual. Begitu juga dengan pemafaatan kotoran sapi menjadi biogas, kegiatan tersebut pernah di uji cobakan hanya dengan menggunakan alat seadanya yaitu drum dan selang tetapi tidak diterapkan oleh petani. Sehinggga dengan demikian, apabila meningkatnya sarana dan prasarana berupa alat dan bahan yang dimiliki oleh petani akan semakin memotivasi petani dalam menerapkan integrasi sawit.

\section{Analisis Hubungan Faktor-Faktor Internal dan Eksternal dengan Motivasi Sosiologis Petani dalam Integrasi Sawit Sapi}

Adapun hasil analisis data tentang hubungan antara faktor-faktor internal dan eksternal dengan motivasi sosiologis petani dalam integrasi sawit sapi di daerah penelitian yang dilakukan dengan menggunakan uji korelasi Spearman dapat dilihat pada Tabel 3 berikut.

Tabel 3. Analisis Hubungan Faktor-Faktor Internal dan Eksternal dengan Motivasi Sosiologis Petani dalam Integrasi Sawit Sapi

\begin{tabular}{lcccc}
\hline \multicolumn{1}{c}{ Variabel } & $\mathrm{r}_{\mathrm{s}}$ & $\mathrm{Sig}$ & $\mathrm{t}$ hit & $\mathrm{t}$ tabel \\
\hline Faktor Internal & & & & \\
\hline $\begin{array}{l}\text { 1. Pendidikan : } \\
\text { a. Pendidikan }\end{array}$ & 0,096 & 0,526 & 0,642 & 2,015 \\
$\begin{array}{l}\text { Formal } \\
\text { b. Pendidikan }\end{array}$ & 0,247 & 0,098 & 1,744 & 2,015 \\
$\begin{array}{l}\text { Nonformal } \\
\text { 2. Pengalaman }\end{array}$ & 0,084 & 0,580 & 0,561 & 2,015 \\
beternak & & & & \\
$\begin{array}{l}\text { 3. Jumlah } \\
\text { ternak }\end{array}$ & $0,350^{*}$ & 0,017 & 2,645 & 2,015 \\
$\begin{array}{l}\text { 4. Tingkat } \\
\text { Kosmopolitan }\end{array}$ & $0,372^{*}$ & 0,011 & 2,863 & 2,015 \\
$\begin{array}{l}\text { Faktor } \\
\begin{array}{l}\text { Eksternal } \\
\text { 5. Dukungan } \\
\text { dari pihak luar }\end{array}\end{array}$ & 0,072 & 0,634 & 0,480 & 2,015 \\
$\begin{array}{l}\text { 6. Ketersedia- } \\
\text { an Sumber }\end{array}$ & 0,042 & 0,783 & 0,279 & 2,015 \\
$\begin{array}{l}\text { Kredit } \\
\text { 7. Ketersedia- } \\
\text { an Sarana }\end{array}$ & & & & \\
\hline
\end{tabular}

\begin{tabular}{lcccc}
\hline \multicolumn{1}{c}{ Variabel } & $\mathrm{r}_{\mathrm{s}}$ & $\mathrm{Sig}$ & $\mathrm{t}$ hit & $\mathrm{t}$ tabel \\
\hline $\begin{array}{l}\text { Prasarana : } \\
\text { a. Ketersedia- } \\
\text { an Alat dan }\end{array}$ & $-0,116$ & 0,444 & $-0,779$ & 2,015 \\
$\begin{array}{l}\text { Bahan } \\
\text { b. Ketersedia- } \\
\text { an Sumber }\end{array}$ & $-0,035$ & 0,817 & $-0,232$ & 2,015 \\
$\begin{array}{l}\text { Input } \\
\begin{array}{l}\text { 8. Jaminan } \\
\text { Pasar }\end{array}\end{array}$ & 0,228 & 0,127 & 1,595 & 2,015 \\
$\begin{array}{l}\text { 9. Kemudahan } \\
\text { dalam }\end{array}$ & $0,288^{*}$ & 0,052 & 2,083 & 2,015 \\
$\begin{array}{l}\text { Penerapan } \\
\begin{array}{l}\text { 10. Keuntu- } \\
\text { ngan }\end{array}\end{array}$ & $-0,116$ & 0,442 & $-0,779$ & 2,015 \\
\hline
\end{tabular}

Berdasarkan Tabel 2 di atas diketahui bahwa faktor-faktor internal (pendidikan dan pengalaman beternak) serta faktor-faktor eksternal (dukungan dari pihak luar, ketersediaan sumber kredit, ketersediaan alat dan bahan, ketersediaan sumber input, jaminan pasar, dan keuntungan) tidak memiliki hubungan yang signifikan dengan motivasi sosiologis petani dalam integrasi sawit sapi. Sedangkan faktor-faktor internal yang memiliki hubungan signifikan dengan motivasi sosiologis petani dalam integrasi sawit sapi, antara lain:

a. Jumlah ternak dengan diperolehnya nilai $t$ hitung $(2,645)>\mathrm{t}$ tabel $(2,015)$. Hal ini didukung oleh hasil penelitian Alam (2014) kepemilikian jumlah ternak yang banyak dapat berdampak terhadap peningkatan status sosial di masyarakat. Hal ini juga yang senantiasa mendorong peternak untuk dapat saling meningkatkan keterampilan beternak yang lebih baik agar hasil produksi yang diperoleh juga optimal.

b. Tingkat kosmopolitan dengan diperolehnya nilai $\mathrm{t}$ hitung $(2,863)>\mathrm{t}$ tabel $(2,015)$. Hal ini sesuai dengan pernyataan Roger dalam Saraswati dan Tinjung (2018) yang menyatakan bahwa pandangan petani akan 
semakin kosmopolitan jika petani semakin sering berhubungan dengan orang luas termasuk penyuluh. Begitu juga dengan hasil pengkajian ini semakin meningkatnya tingkat kekosmopolitan dari petani dalam mencari dan mendapatkan informasi maka akan semakin tinggi motivasi sosiologis petani karena petani merasa bahwa pentingnya pengaruh-pengaruh dari luar kelompok masyarakat kepada petani guna membangun kerja sama, relasi, maupun meningkatkan kerukuran antar petani yang dapat diperoleh melalui kegiatan penyuluhan, petani menyatakan bahwa biasanya materi penyuluhan yang dibawakan tidak terkait dengan integrasi sawit sapi mengakibatkan petani kurang berkoordinasi dengan penyuluh dan petani masih kurang memanfaatkan keberadaan penyuluh sebagai sumber informasi.

Selain faktor-faktor internal ada juga faktor eksternal (kemudahan dalam penerapan) yang memiliki hubungan signifikan dengan motivasi sosiologis petani dalam integrasi sawit sapi. Hal ini sesuai dengan pernyataan para petani di daerah penelitian bahwa integrasi sawit sapi mudah untuk diterapkan. Walaupun integrasi sawit sapi mudah untuk diterapkan, para petani di daerah penelitian juga melakukan kerja sama antar sesama petani dan juga memiliki rotasi jadwal yang telah disusun untuk bertugas menjaga ternak yang sedang digembalakan ataupun ketika sedang dikandangkan dimalam hari.

\section{KESIMPULAN DAN SARAN}

Tingkat motivasi ekonomi dan sosiologis petani dalam penerapan integrasi sawit sapi masing-masing berada pada kategori sedang yang artinya para petani di daerah penelitian melakukan penerapan integrasi sawit sapi didorong oleh keinginan untuk memperoleh pendapatan yang lebih tinggi dan mempererat kerukunan. Selanjutnya dapat disimpulkan bahwa untuk motivasi ekonomi petani dalam menerapkan integrasi sawit sapi hanya memiliki hubungan yang signifikan dengan 3 (tiga) faktor-faktor eksternal. Sedangkan untuk motivasi sosiologis petani dalam menerapkan integrasi sawit sapi hanya memiliki hubungan yang signifikan dengan 2 (dua) faktor-faktor internal dan 1 (satu) faktor eksternal petani.

\section{DAFTAR PUSTAKA}

Alam. A., S. Dwijatmiko, \& W. Sumekar. (2014). Motivasi Peternak terhadap Budidaya Sapi Potong di Kabupaten Buru Provinsi Maluku.Jawa Tengah: Fakultas Peternakan Universitas Diponegoro.

Badan Pusat Statistik Provinsi Sumatera Utara. (2018). Provinsi Sumatera Dalam Angka 2017. Medan.

Bamualim. A.M., Maddarisa F, Pendra Y, Mawardi E, \& Asmak. (2015). Kajian Inovasi Integrasi Tanaman-Ternak melalui Pemanfaatan Hasil Ikutan Tanaman Sawit untuk Meningkatkan Produksi Sapi Lokal Sumatera Barat. Sumatera Barat: Jurnal Fakultas Peternakan Universitas Andalas.

Chandrayani, P.M.W \& Natha, K.S. (2016). Pengaruh Harga, Kurs Dollar Amerika Serikat dan Produksi Terhadap Ekspor Vanili di Provinsi Bali Tahun 1991-2013. Ekonomi Pembangunan UNUD, 5 (2) : 236-259. 
Direktorat Jenderal Peternakan dan Kesehatan Hewan Kementerian Pertanian RI. (2017). Statistik Peternakan dan Kesehatan Hewan 2017. Jakarta.

Direktorat Pangan dan Pertanian. Badan Perencanaan Pembangunan Nasional (2013). Studi Pendahuluan Rencana Pembangunan Jangka Menengah Nasional (RPJMN) Bidang Pangan dan Pertanian 2015-2019. Jakarta:Bappenas.

Fauzi, Y., Widyastuti Y.E., Satyawibawa I, \& Paeru, R.H. (2012). Kelapa Sawit. Depok: Penebar Swadaya.

Kementerian Pertanian RI. (2015). Rencana Strategis Kementerian Pertanian 20152019. Jakarta.

Kompas. (2017). Kementan Akui Indonesia Masih Defisit Daging Sapi. Diakses [26 April 2019]. Dikutip dari https://ekonomi.kompas.com/read/2017/0 6/22/071604626/kementan.akui.indonesia. masih.defisit.daging.sapi.

Matondang, R.H dan Rusdiana, S. (2013). Langkah-Langkah Strategis dalam Mencapai Swasembada Daging Sapi/Kerbau 2014. J.Litbang Pert. 32 (3), 131-139.

Prijambodo. (2018). Monitoring dan Evaluasi. Bogor:IPB Press.

Ruhimat, Idin Saefudin. (2015). Tingkat Motivasi Petani dalam Penerapan Sistem Agroforestry.Jurnal Balai Penelitian Teknologi Agroforestry.

Rukka, H. \& Arman, W. (2013). FaktorFaktor yang Mempengarhui Motivasi Petani dalam Pelaksanaan Kegiatan P2BN di Kecamatan Barru, Kabupaten Baru.Gowa: Jurnal Sekolah Tinggi Penyuluhan Pertanian Gowa.

Riadi, E. (2015). Metode Statistika Parametrik \& Nonparametrik. Tangerang : Pustaka Mandiri.

Silalahi, Masrizal, \& Abusari M. (2015). Motivasi Petani dalam Usahatani Tanaman Gambir (Uncaria gambir roxb) di Kecamatan Sutera Kabupaten Pesisir
Selatan. Medan: Sekolah Tinggi Penyuluhan Pertanian Medan

Sirait, P., Zulkifli L, \& Murbanto, S. (2015). Analisis Sistem Integrasi Sapi dan Kelapa Sawit Dalam Meningkatkan Pendapatan Petani Di Kabupaten Labuhanbatu.Medan: Universitas Medan Area.

Supriana, T \& Barus, R. (2010). Statistik Nonparametrik : Aplikasi dalam Bidang Sosial Ekonomi Pertanian. Medan : USU Press.

Suryana, Y.M. (2015). Prospek Pengembangan Integrasi Sawit sapi di Kalimantan Selatan. Kalimantan Selatan : Jurnal Balai Pengkajian Teknologi Pertanian Kalimantan Selatan. 